ISSN 1678-3921

Journal homepage: www.embrapa.br/pab

For manuscript submission and journal contents, access: www.scielo.br/pab
Luciana Marques de Carvalho(1凶) (iD, Hélio Wilson Lemos de Carvalho(1) (iD and Claudio Guilherme Portela de Carvalho(2) (1D)

(1) Embrapa Tabuleiros Costeiros, Avenida Beira mar, no 3.250, CEP 49025-480 Aracaju, SE, Brazil.

Email: luciana.carvalho@embrapa.br, Helio.carvalho@embrapa.br

(2) Embrapa Soja, Caixa Postal 231, CEP 86001-970 Londrina, PR, Brazil.

E-mail: portela.carvalho@embrapa.br

$\bowtie$ Corresponding author

Received

November 18, 2019

Accepted

April 20, 2020

How to cite

CARVALHO, L.M. de; CARVALHO, H.W.L. de; CARVALHO, C.G.P. de. Yield and photosynthetic attributes of sunflower cultivars grown under supplemental irrigation in the semiarid region of the Brazilian Northeast. Pesquisa Agropecuária Brasileira, v. 55 e01715, 2020. DOI: https://doi.org/10.1590/ S1678-3921.pab2020.v55.01715.

\section{Yield and photosynthetic attributes of sunflower cultivars grown under supplemental irrigation in the semiarid region of the Brazilian Northeast}

\begin{abstract}
The objective of this work was to identify the sunflower (Helianthus annuus) cultivar with the highest yield potential for cultivation in the semiarid region of the Brazilian Northeast, under field conditions, with supplementary irrigation. Plant photosynthetic performance and yield were determined in field trials. The experiments were carried out in a randomized complete block design with 12 cultivars planted at $0.70 \times 0.30 \mathrm{~m}$. Net photosynthetic rates above $27 \mu \mathrm{mol} \mathrm{m}^{-2} \mathrm{~s}^{-1}$ and average achene yield of 2,364.68 $\mathrm{kg} \mathrm{ha}^{-1}$ and oil yield $961.96 \mathrm{of} \mathrm{kg} \mathrm{ha}^{-1}$ were determined. This performance was achieved due to: high stomatal conductance in 'Aguara 4', 'BRS 322', and 'CF101', low water loss through transpiration in 'M 734', 'BRS 321', 'BRS 324', 'BRS 387', and 'Helio 251', or high-intrinsic photosynthetic efficiency in 'Helio 251' and 'BRS 387'. Most cultivars provided grain amounts and oil contents similar to those of cultivars grown in the largest Brazilian producing areas. The cultivars that provide the highest yield in the Brazilian semiarid region, when grown under supplementary irrigation, are 'Aguara 4', 'CF 101', and 'BRS 322' with a high achene and oil yield, and 'M 734' with high achene yield. The less susceptible cultivars to severe water deficit are 'Helio 251' and 'BRS 387' with a highintrinsic photosynthetic efficiency.
\end{abstract}

Index terms: Helianthus annuиs, grain, oil, stomatal conductance.

\section{Rendimento e atributos fotossintéticos de cultivares de girassol cultivadas com irrigação suplementar na região do Semiárido do Nordeste brasileiro}

Resumo - O objetivo deste trabalho foi identificar a cultivar de girassol (Helianthus annuus) com maior potencial produtivo para cultivo no Semiárido Nordestino, em condições de campo, com irrigação suplementar. Determinaram-se o desempenho fotossintético e o rendimento da planta em ensaios de campo. Os experimentos foram realizados em delineamento de blocos ao acaso, com 12 cultivares plantadas em espaçamento $0,70 \times 0,30 \mathrm{~m}$. Foram determinadas taxas fotossintéticas acima de $27 \mu \mathrm{mol} \mathrm{m}^{-2} \mathrm{~s}^{-1}$ erendimento médio de grãos de 2.364,68 $\mathrm{kg} \mathrm{ha}^{-1} \mathrm{e}$ de óleo de $961,96 \mathrm{~kg} \mathrm{ha}^{-1}$. Este desempenho foi possível em razão da: alta condutância estomática em 'Aguara 4', 'BRS 322' e 'CF 101', baixa perda de água por transpiração em 'M 734', 'BRS 321', 'BRS 324', 'BRS 387' e 'Helio 251', ou alta eficiência fotossintética no uso de água em 'Helio 251' e 'BRS 387'. A maioria das cultivares forneceu grãos e óleo em quantidades similares àquelas das maiores áreas produtoras brasileiras. As 
cultivares com maior rendimento no Semiárido brasileiro, cultivadas com irrigação suplementar, são 'Aguara 4', 'CF 101' e 'BRS 322' com alto rendimento de aquênios e óleo e 'M 734' com alto rendimento de aquênios. As cultivares de menor susceptibilidade ao estresse hídrico severo são 'Helio 251' e 'BRS 387' com maior eficiência fotossintética no uso da água.

Termos para indexação: Helianthus annuus, grãos, óleo, condutância estomática.

\section{Introduction}

Sunflower (Helianthus annuus L.) stands out among oilseeds as it contributes for about $12 \%$ of the world's edible oil production (Saba et al., 2016). The world demand for sunflower oil has been increasing on average by $1.8 \%$ per year, whereas the internal demand in Brazil increases on average at $13 \%$ per year (Rosa et al., 2009). However, Brazilian sunflower production is still small, and there is a need of imports to meet the country's demand (Brasil, 2018).

The largest Brazilian producing areas are in the Southern and Central regions, where the annual rainfall supports the water requirements of the sunflower cultivation (Dalchiavon et al., 2016). However, in a number of countries worldwide, such as Turkey and Italy, sunflower is also grown in semiarid areas due to its drought escape behavior worldwide (Onemli \& Gucer, 2010; Garofalo \& Rinaldi, 2015; Kaya et al., 2015). The Brazilian semiarid region is the world's most densely populated dry land region with more than 53 million inhabitants. Inside this region lies the so called "drought polygon", an area of about $940,000 \mathrm{~km}^{2}$ where risk of drought is above $60 \%$ (Krol \& Bronstert, 2007; Marengo \& Bernasconi, 2015). However, part of these areas might be irrigated. Both irrigated and rainfed farming are practiced in the potentially irrigated lands (Krol \& Bronstert, 2007). Therefore, the advance of sunflower production areas, in the Brazilian semiarid zones, may be one of the alternatives for increasing the Brazilian production and income for farmers.

Some authors categorized the sunflower as a low to medium drought sensitive crop due to its welldeveloped root system, the capacity to avoid transient wilting, and ability to withstand short periods of severe soil-water deficit (Saba et al., 2016; Hussain et al., 2018). However, long periods of deficit at any growth period cause leaf drying and diminish the plant photosynthetic performance with a subsequent reduction of seed yield (Ghaffari et al., 2012; Pekcan et al., 2015). Several management strategies are used to minimize water stress and to reduce the yield gap between the actual and the maximum yield in sunflower grown in water-limited areas, including droughttolerant genotypes (Onemli \& Gucer, 2010; Pekcan et al., 2015) and supplemental irrigation (Anastasi et al., 2010; Kaya et al., 2015; Birck et al., 2017). In addition, sowing in the rainy season ensures available water at the initial growth stages, which may result in good vegetative growth, although the subsequent lowmoisture availability at flowering and grain filling stages may significantly reduce the yield due to hightranspiration demands (Aboudrare et al., 2006).

The choice of productive cultivars in semiarid environments constitutes an important low-cost input (Birck et al., 2017). Many studies worldwide have involved the evaluation of morphological and physiological characteristics of sunflower because of the economic importance of its oilseed. Furthermore, according to Rauf \& Sadaquat (2008), plant breeders focused mainly on the lower-leaf canopy and reduced transpiration over the past decades, which are not necessarily associated with high yield in sunflower plants. Thus, they would have evolved cultivars with poor yield under stress condition. In addition, most of these studies have been conducted in greenhouses or growth chambers and include a few cultivars (Hussain et al., 2018). In Brazil, the evaluation and selection of hybrids and varieties (open-pollinated population) of sunflower from several companies have been mainly performed in areas where water is not limiting (Dalchiavon et al., 2016). However, few studies were done in the semiarid region of the Brazilian Northeast (Carvalho et al., 2018; Souza et al., 2019).

The objective of this work was to identify the sunflower cultivar with the highest yield potential, for cultivation in the semiarid region of the Brazilian Northeast, under field conditions, with supplementary irrigation.

\section{Materials and Methods}

Four field experiments with sunflower cultivars (Helianthus annuus L.) were performed during the rainy-season cultivation (June-November) of 2012, 2013, 2014, and 2015. They were carried out in Poço 
Redondo (9 $47^{\prime} \mathrm{S}, 37^{\circ} 1^{\prime} \mathrm{W}$, at $188 \mathrm{~m}$ altitude), in the state of Sergipe (SE), Brazil, in an area with Chromic Luvisol (IBGE, 2011; Moura et al., 2017; Santos et al., 2018), a typical soil of the Brazilian Northeastern's semiarid. According to Köppen-Geiger the climate classification is classified as Bsh (extremely hot and semiarid). The scarce and irregular rainfalls are often concentrated between May and August, when crops are grown. Air temperatures above $29^{\circ} \mathrm{C}$ were observed in 47 (in 2012), 58 (in 2013), 66 (in 2014), and 56 (in 2015) days, including some days during the field trials (Table 1). Weather records during the of experimental period were collected by an agrometeorological station [TRMM.5503 (9007655)] installed in Canindé de São Francisco $\left(9.75^{\circ} \mathrm{S}, 38^{\circ} \mathrm{W}\right.$, at $147 \mathrm{~m}$ altitude), in the state of Sergipe, which is located $15 \mathrm{~km}$ from the experimental site (Agritempo..., 2017).

Although the experimental site is in the semiarid environment, it is located inside the irrigated perimeter of the São Francisco River. Thus, the farmers usually irrigate their crops, during part of the day, to mitigate drought effects and avoid great losses of the productivity. Similarly to them, and because of the scarcity and irregularity of the rain distribution associated to the local high-air temperatures, supplemental water was provided to plants, for $40 \mathrm{~min}$ every day in the morning, by micro sprinklers $\left(7 \mathrm{~L} \mathrm{~m}^{-2}\right.$ per day).

Each trial was carried out in a randomized complete block design, with twelve treatments (cultivars) and four replicates. Each four-row plot was $6.0 \mathrm{~m}$ long, spaced at $0.70 \mathrm{~m}$ apart, with $0.30 \mathrm{~m}$ between holes, in a total of 20 plants per row, and 80 plants per plot. Additionally, border rows on each side of the plot, as well as border plants on each end of the plot, were installed using plants of the same cultivar as the one being tested. The evaluated sunflower cultivars, adapted to the Brazilian central and south regions (Dalchiavon et al., 2016), are

Table 1. Weather data during the growth period of sunflower (2012-2015), in the municipality of Poço Redondo, in the state of Sergipe, Brazil(1).

\begin{tabular}{|c|c|c|c|c|c|c|}
\hline \multirow[t]{3}{*}{ Year } & \multirow[t]{3}{*}{ Month } & \multicolumn{2}{|c|}{ Rainfall } & \multicolumn{3}{|c|}{ Air temperature } \\
\hline & & \multirow{2}{*}{$\begin{array}{l}\text { Total volume } \\
\text { (mm) }\end{array}$} & \multirow{2}{*}{$\begin{array}{c}\text { No-rain days } \\
\qquad\left(\mathrm{n}^{\circ}\right)\end{array}$} & \multicolumn{2}{|c|}{ Maximum } & \multirow[t]{2}{*}{ Median $\left({ }^{\circ} \mathrm{C}\right)$} \\
\hline & & & & $\left({ }^{\circ} \mathrm{C}\right)$ & (n ${ }^{\circ}$ of days) & \\
\hline \multirow{5}{*}{2012} & June & 0 & 30 & 32 & 8 & 25.38 \\
\hline & July & 0 & 31 & 30 & 2 & 23.4 \\
\hline & August & 6.96 & 30 & 31 & 2 & 23.4 \\
\hline & September & 5.76 & 29 & 34 & 4 & 25.15 \\
\hline & October & 5.61 & 30 & 35 & 1 & 26.5 \\
\hline \multirow{5}{*}{2013} & June & 0 & 30 & 32 & 4 & 25.7 \\
\hline & July & 56.1 & 27 & 30 & 2 & 24.03 \\
\hline & August & 0 & 31 & 32 & 1 & 24.5 \\
\hline & September & 0 & 30 & 35 & 2 & 26.15 \\
\hline & October & 7.17 & 30 & 37 & 1 & 26.82 \\
\hline \multirow{5}{*}{2014} & June & 0 & 30 & 33 & 1 & 25.3 \\
\hline & July & 7.35 & 30 & 32 & 2 & 24.56 \\
\hline & August & 7.62 & 29 & 32 & 1 & 23.82 \\
\hline & September & 0 & 30 & 36 & 1 & 25.68 \\
\hline & October & 9.42 & 30 & 34 & 6 & 26.32 \\
\hline \multirow{5}{*}{2015} & June & 16.26 & 29 & 32 & 4 & 24.88 \\
\hline & July & 44.7 & 28 & 30 & 5 & 24.23 \\
\hline & August & 15.42 & 30 & 33 & 1 & 24.03 \\
\hline & September & 0 & 30 & 34 & 10 & 26.28 \\
\hline & October & 0 & 31 & 37 & 1 & 27.50 \\
\hline
\end{tabular}

${ }^{(1)}$ Data obtained from the weather station TRMM/Agricola, installed at $9.88^{\circ} \mathrm{S}, 37.6^{\circ} \mathrm{W}$ (Agritempo..., 2017). 
the following ones: 'M 734' (Dow AgroSciences, São Paulo, SP, Brazil); 'Aguara 4', 'Aguara 6', and 'Olisun 3' (Atlântica Sementes, Curitiba, PR, Brazil); 'CF 101' (Advanta, Campinas, SP, Brazil); 'Helio 251' (Heliagro do Brasil, Araguari, MG, Brazil); 'BRS 321', 'BRS 322', 'BRS 323', 'BRS 387', (Embrapa, Brasília, DF, Brazil). Except for 'BRS 324' and 'Embrapa122' (openpollinated populations), all others are simple hybrids. Seed were obtained from the national sunflower genebank of Embrapa (Brasília, DF, Brazil). In all trials, the fertilization was performed by taking into account the chemical analysis of the soil. Sowing occurred in June, during the rainy season, for all trials. After planting and emerging, plants were thinned, and only one was left in each hole. The soil between cultivation rows was maintained free of weeds using post-emergence herbicides. All recommended cultural practices were followed to allow of the suitable plant development (Oliveira \& Rosa, 2013).

In September 2014 (90 days after sowing), at the beginning offlowering(R4-R5 stage), leafgas exchange rates and associated attributes were measured on two fully expanded leaves $(3,4$, acropetally numbered) of three plants per plot, which were chosen at random in each plot. The measurements were taken from plants between 9:00-10:00 h. Similarly to Tabatabaei et al. (2012), rates of net photosynthetic (Pn), stomatal conductance to water vapor (gs), transpiration (E), and the estimate of intrinsic water-use photosynthetic efficiency (Pn/gs) were performed in the field. Measurements were taken on intact, individually attached leaves by using a portable infrared $\mathrm{CO}_{2}$ analyzer (LCpro+, ADC, Hoddesdon, UK), with 1800 $\mu \mathrm{mol} \mathrm{m} \mathrm{m}^{-2} \mathrm{~s}^{-1}$ photosynthetic active radiation supplied by a light unit mounted on the top of leaf chamber, and 365 ppm ambient $\mathrm{CO}_{2}$.

In all trials (2012-2015) the achenes (grains) were harvested at maturity and their weights were recorded. From these data, the achene yield was calculated $\left(\mathrm{kg} \mathrm{ha}^{-1}\right)$, and the achene's oil percentage and the oil yield $\left(\mathrm{kg} \mathrm{ha}^{-1}\right)$ were determined. The oil percentage content was determined using petroleum ether as solvent, and the oil yield was calculated from the oil percentage and the achene yield (Grunvald et al., 2014).

The recorded data were subjected to the analysis of variance, and the cultivars were grouped using the Scott-Knott's test when significant effects were detected by the F-test, at 5\% probability. Previously, root square transformations were used for all data that did not follow the normal distribution. In addition, data of achene and oil yield from the average of the years (2012-2015) were statistically analyzed for simple correlation with grain and oil yields from 2014.

\section{Results and Discussion}

Sunflower cultivars differed from each other for achene and oil yield, and oil content (Table 2). Yield means by the sunflower cultivars in the present work were higher than those reported for plants grew in Campo Novo do Parecis, in the state of Mato Grosso, the largest Brazilian producer of sunflower (Birck et al., 2017). They were also similar to those found in cultivars planted in the Brazilian southern and central states (Dalchiavon et al., 2016). The desirable oil content in achenes - from 37.48 to $43.41 \%$ - was observed in the present work, in most of the studied sunflower cultivars, taking into account the reference of $40 \%$ for oil content in the achenes quoted by Dalchiavon et al. (2016). Carvalho et al. (2018) also verified the high yield and quality of the oil of sunflower plants, in the conditions of Northeast Brazil, including the state of Sergipe. Our results confirm the production feasibility of sunflower in Brazilian Northeast, particularly in the municipality of Poço Redondo, in the semiarid region of the Sergipe state, at least where supplementary watering (rainfall + supplementary irrigation) is available. It is also important to highlight that a significant correlation was found for yield in the period 2012-2015, and that recorded in 2014 for achene (0.82) and oil averages (0.81), which indicates the similarity among the field trials performed in all years.

Total rainfall recorded in Poço Redondo, across the years 2012 to 2015, was low during every experimental period, and ranged from 12.72 to $76.38 \mathrm{~mm}$ (Table 1). This fact proved the need for supplemental irrigation on crops. According to Marengo et al. (2017), the drought intensified in 2012 in the semiarid region of Northeast Brazil extended onto 2015, and is considered as the most severe drought of the last decades. Except for sunflower 'BRS 321', all the other cultivars showed lower-achene yields in 2012, and there was no significant difference between them. The climatic data (Table 1) and the achene yield (Table 2) suggest that water deficit may have occurred across the years 2012-2015. According to Lamaoui et al. (2018), water 
stress takes place when humidity in the soil and in the atmosphere is low, and the ambient-air temperature is high. These conditions would be the result of an imbalance between the evapotranspiration flux and water intake from the soil. Based on these data, we can infer that a more severe water deficit possibly occurred in 2012 and 2015, and a milder one in 2014.

Sunflower 'M 734' provided the greatest yield of achene in 2014, followed by 'Aguara 4', 'CF 101', 'Helio 251', 'BRS 322' (Table 2). In average, for four consecutive years (2012-2015), the largest yield of achene was obtained by 'M 734' and 'Aguara 4', followed by 'CF 101', 'Helio 251', 'BRS 322', 'Aguara 6', and 'Olisun 3'. The highest-oil percentage was recorded in 'BRS 321', 'BRS 324', 'CF 101', and 'Aguara 4', in contrast to the lowest-oil percentage found for 'M 734' and 'BRS 387' (Table 2). Therefore, sunflower 'Aguara 4 ' and 'CF 101' outstood for their biggest achene and oil yield. Except for 'M 734' and 'BRS 387', the evaluated cultivars were capable of producing achenes with the desirable oil content, in Poço Redondo, SE, in the Brazilian semiarid zone.

Most of the sunflower cultivars achieved the greatest yield in 2014, when few rains fell down in July, at the flowering stage, and in August, at the filling-grain stage, in contrast to no rain in July 2012, and much rain in July 2013 and 2015 (Table 1). In addition, days with higher-air temperatures were more frequent in 2015 than in 2014. In addition, the lowest means for achene yield were found in 2012 and 2015. Chimenti \& Hall (2001) suggest that a high-rainfall volume at the flowering period impairs the fertilization of the flowers and compromises the achene production due to the impact of the rains on flowers. They also state that air temperatures above $30^{\circ} \mathrm{C}$ significantly increase the number of unfilled (flats) grains.

In the present study, the averages of stomatal conductance rate varied from 0.060 to $0.240 \mathrm{~mol}$ $\mathrm{H}_{2} \mathrm{O} \mathrm{m}^{-2} \mathrm{~s}^{-1}$. Some cultivars showed a greater stomatal closure ('BRS 321', 'BRS 324', 'BRS 387', and 'Helio 251 '), which allows of the decrease of water loss by transpiration. However, other cultivars displayed a high-stomatal conductance rate ('Aguara 4', followed by 'BRS 322' and 'CF 101'). Garofalo \& Rinaldi (2015) found a lower rate of stomatal conductance for sunflower plants grew in a greenhouse under controlled water deficit. According to them, the stomatal closure favors the reduction of water loss through the leaves due to the transpiration. In addition, they suggest that the stomatal closure would be the main adaptation mechanism to water stress for sunflower plants that had not yet reached the stage of full flowering.

Table 2. Means of oil and achene yield, and oil percentage of sunflower cultivars (Helianthus annuus), and means of achene yield per year, in the municipality of Poço Redondo, in the state of Sergipe, in the semiarid region of Brazilian Northeast, from 2012 to $2015^{(1)}$.

\begin{tabular}{lccccccc}
\hline Cultivar & Oil yield $\left(\mathrm{kg} \mathrm{ha}^{-1}\right)$ & \multicolumn{3}{c}{ Achene yield per year $\left(\mathrm{kg} \mathrm{ha}^{-1}\right)$} & \multicolumn{2}{c}{$\begin{array}{c}\text { Mean } \\
\text { Oil percentage }(\%)\end{array}$} \\
\cline { 2 - 6 } & $2012-2015$ & 2012 & 2013 & 2014 & 2015 & $2012-2015$ & $2012-2015$ \\
\hline M 734 & $1,023.54 \mathrm{~b}$ & $2,093 \mathrm{aC}$ & $2,699 \mathrm{bB}$ & $3,795 \mathrm{aA}$ & $2,352 \mathrm{aC}$ & $2,734.63 \mathrm{a}$ & $37.48 \mathrm{c}$ \\
Aguara 4 & $1,131.30 \mathrm{a}$ & $2,204 \mathrm{aB}$ & $3,205 \mathrm{aA}$ & $3,077 \mathrm{bA}$ & $2,405 \mathrm{aB}$ & $2,722.81 \mathrm{a}$ & $41.41 \mathrm{a}$ \\
CF 101 & $1,143.40 \mathrm{a}$ & $2,019 \mathrm{aC}$ & $2,990 \mathrm{aB}$ & $3,243 \mathrm{bA}$ & $2,124 \mathrm{bC}$ & $2,593.81 \mathrm{~b}$ & $43.41 \mathrm{a}$ \\
Helio 251 & $1,004.44 \mathrm{~b}$ & $1,768 \mathrm{aD}$ & $2,875 \mathrm{aB}$ & $3,317 \mathrm{bA}$ & $2,183 \mathrm{bC}$ & $2,535.63 \mathrm{~b}$ & $39.58 \mathrm{~b}$ \\
Aguara 6 & $1,020.22 \mathrm{~b}$ & $2,002 \mathrm{aC}$ & $2,948 \mathrm{aA}$ & $2,713 \mathrm{cA}$ & $2,356 \mathrm{aB}$ & $2,504.75 \mathrm{~b}$ & $40.65 \mathrm{~b}$ \\
Olisun 3 & $999.75 \mathrm{~b}$ & $2,049 \mathrm{aB}$ & $2,818 \mathrm{aA}$ & $2,868 \mathrm{cA}$ & $2,130 \mathrm{bB}$ & $2,466.10 \mathrm{~b}$ & $40.06 \mathrm{~b}$ \\
BRS 322 & $966.96 \mathrm{~b}$ & $1,984 \mathrm{aC}$ & $2,588 \mathrm{bB}$ & $3,125 \mathrm{bA}$ & $2,021 \mathrm{cB}$ & $2,429.19 \mathrm{~b}$ & $39.91 \mathrm{~b}$ \\
BRS 323 & $871.07 \mathrm{c}$ & $2,002 \mathrm{aB}$ & $2,428 \mathrm{bA}$ & $2,382 \mathrm{dA}$ & $1,934 \mathrm{cB}$ & $2,186.13 \mathrm{c}$ & $39.78 \mathrm{~b}$ \\
Embrapa 122 & $843.17 \mathrm{c}$ & $1,940 \mathrm{aB}$ & $1,880 \mathrm{cB}$ & $2,561 \mathrm{cA}$ & $1,950 \mathrm{cB}$ & $2,082.63 \mathrm{c}$ & $40.36 \mathrm{~b}$ \\
BRS 387 & $797.86 \mathrm{c}$ & $1,930 \mathrm{aB}$ & $1,888 \mathrm{cB}$ & $2,410 \mathrm{dA}$ & $1,984 \mathrm{cB}$ & $2,052.75 \mathrm{c}$ & $38.73 \mathrm{c}$ \\
BRS 324 & $872.92 \mathrm{c}$ & $1,861 \mathrm{aB}$ & $1,833 \mathrm{cB}$ & $2,735 \mathrm{cA}$ & $1,748 \mathrm{~dB}$ & $2,044.19 \mathrm{c}$ & $42.23 \mathrm{a}$ \\
BRS 321 & $868.93 \mathrm{c}$ & $1,944 \mathrm{aA}$ & $2,125 \mathrm{cA}$ & $2,218 \mathrm{dA}$ & $1,810 \mathrm{~dB}$ & $2,023.63 \mathrm{c}$ & $42.90 \mathrm{a}$ \\
\hline Average & 961.96 & $1,983 \mathrm{C}$ & $2,523 \mathrm{~B}$ & $2,870 \mathrm{~A}$ & $2,083 \mathrm{C}$ & $2,364.68$ & 40.54 \\
\hline
\end{tabular}

${ }^{(1)}$ Means followed by equal letters, lowercase in the columns and uppercase in the rows only for achene yield, do not differ by Scott-Knot's test, at $5 \%$ probability. 
Similarly to the stomatal conductance rate (gs), the intrinsic photosynthetic efficiency ( $\mathrm{Pn} / \mathrm{gs}$ ) showed a wide variation among cultivars: from 119.80 to 479.01 (Table 3). The lower intrinsic photosynthetic efficiency in water use indicates a higher susceptibility to water deficit, whether supplemental irrigation is available or not (Casadebaig et al., 2011). In contrast to these cultivars, the high-achene yield found in 'Helio 251' (although lower than in 'Aguara 4') may be explained by its lowest rates of stomatal aperture and transpiration, associated with its high intrinsic photosynthetic efficiency. The high efficiency of 'Helio 251' suggests that it has a greater potential for water deficit tolerance, as well as potential to produce more achene in drier years. A similar performance was found in the cultivar 'BRS 387'. Despite their lower achene yield, 'BRS 321' and 'BRS 387' stood out for their higher stability across the years 2012-2015, which also suggests their great suitability to local conditions.

In contrast to gs and $\mathrm{Pn} / \mathrm{gs}$, the net photosynthetic rate of the studied sunflower cultivars displayed a narrow range of variation, which was between 27.13 and $31.72 \mathrm{mmol}$ of $\mathrm{CO}_{2} \mathrm{~m}^{-2} \mathrm{~s}^{-1}$ (Table 3). Considering only the field studies performed in the semiarid conditions, these values were similar to those reported by Liu \& Shi (2010) and Silva et al. (2013) for plants grew under controlled irrigation. Furthermore, they were also similar to those reported for plants grew in nonirrigated semiarid areas (Tabatabaei et al., 2012; Garofalo \& Rinaldi, 2015; Hussain et al., 2018). Thus, despite the relatively high-air temperatures and number of no-rain days (Table 1), the sunflower cultivars maintained high photosynthetic rates. From this result, we can infer that possibly a possible mildwater deficit only occurred, and it was not able to prevent that these high-net photosynthetic rate were converted into a great achene and oil yield. Lamaoui et al. (2018) suggest that the stomatal closure would have a more inhibitory effect on transpiration of water than on $\mathrm{CO}_{2}$ diffusion into leaf tissues, and then on the net photosynthetic rates.

Silva et al. (2013) verified no significant differences between rates from plants irrigated and from those subjected to natural water stress. In contrast, Cechin et al. (2010), Zlatev \& Lidon (2012), and Ucak (2018) reported decreases of photosynthetic rates for sunflower grew in pots under controlled water deficit. Silva et al. (2013) suggest that the lack of decrease in photosynthetic rates of plants grew in the field is due to the changes of the water status in these plants which

Table 3. Means of net photosynthetic (Pn), transpiration (E), stomatal conductance rates (gs), and intrinsic water-use photosynthetic efficiency (Pn/gs), for sunflower cultivars grew in the municipality of Poço Redondo, in the state of Sergipe, in the semiarid region of Brazilian Northeast ${ }^{(1)}$.

\begin{tabular}{|c|c|c|c|c|}
\hline Cultivar & $\begin{array}{c}\mathrm{Pn} \\
\left(\mu \mathrm{mol} \mathrm{m} \mathrm{m}^{-2} \mathrm{~s}^{-1}\right)\end{array}$ & $\begin{array}{c}\mathrm{E} \\
\left(\mathrm{mmol} \mathrm{m}{ }^{-2} \mathrm{~s}^{-1}\right)\end{array}$ & $\begin{array}{c}\text { gs } \\
\left(\mathrm{mol} \mathrm{m}^{-2} \mathrm{~s}^{-1}\right)\end{array}$ & $\mathrm{Pn} / \mathrm{gs}$ \\
\hline M 734 & $30.61 \mathrm{a}$ & $1.957 \mathrm{c}$ & $0.127 \mathrm{c}$ & $254.47 \mathrm{c}$ \\
\hline Embrapa 122 & $31.72 \mathrm{a}$ & $1.750 \mathrm{c}$ & $0.116 \mathrm{c}$ & $285.62 \mathrm{c}$ \\
\hline BRS 321 & $27.13 b$ & $1.167 \mathrm{~d}$ & $0.076 \mathrm{~d}$ & $368.96 b$ \\
\hline BRS 322 & $31.09 \mathrm{a}$ & $2.670 \mathrm{a}$ & $0.210 \mathrm{~b}$ & $151.47 \mathrm{~d}$ \\
\hline BRS 323 & $31.30 \mathrm{a}$ & $1.760 \mathrm{c}$ & $0.120 \mathrm{c}$ & $274.02 \mathrm{c}$ \\
\hline BRS 324 & $27.84 \mathrm{~b}$ & $1.100 \mathrm{~d}$ & $0.070 \mathrm{~d}$ & $398.64 b$ \\
\hline BRS 387 & $27.16 \mathrm{~b}$ & $1.117 \mathrm{~d}$ & $0.060 \mathrm{~d}$ & $452.66 \mathrm{a}$ \\
\hline Helio 251 & $28.39 b$ & $1.050 \mathrm{~d}$ & $0.060 \mathrm{~d}$ & $479.01 \mathrm{a}$ \\
\hline Aguara 4 & $28,68 b$ & $2.867 \mathrm{a}$ & $0.240 \mathrm{a}$ & $119.80 \mathrm{~d}$ \\
\hline Aguara 6 & $31.04 \mathrm{a}$ & $1.607 \mathrm{c}$ & $0.100 \mathrm{c}$ & $310.99 \mathrm{c}$ \\
\hline Olisun 3 & $30.88 \mathrm{a}$ & $1.733 \mathrm{c}$ & $0.110 \mathrm{c}$ & $284.96 \mathrm{c}$ \\
\hline CF 101 & $30.78 \mathrm{a}$ & $2.360 \mathrm{~b}$ & $0.186 \mathrm{~b}$ & $167.35 \mathrm{~d}$ \\
\hline Average & $29.54 *$ & $1.718^{* *}$ & $0.1195^{* *}$ & $301.13 * *$ \\
\hline Coefficient of variation (\%) & 6.12 & 12.03 & 15.03 & 15.05 \\
\hline
\end{tabular}

${ }^{(1)}$ Means followed by equal letters, do not differ by Scott-knot's test, at $5 \%$ probability. * and **Significant by the F- test, at $5 \%$ and $1 \%$ probability, respectively. 
would be slow and gradual. According to them, this would favor the establishment of the acclimatization mechanism, which includes the morphological and physiological adjustments that provide an escape to the water stress, including an increased root system, reduced the stomatal number and conductance, decreased leaf area, increased leaf thickness, and leaf rolling, or folding to lessen evapotranspiration (Lamaoui et al., 2018).

Silva et al. (2013) warn, however, that instantaneous (transient) measurements of gas exchange might not reflect the authentic physiological behavior of the fieldgrown plants in face of the stress conditions throughout the day and, therefore, need to be evaluated with some caution. Taiz \& Zeiger (2012) reported that there is an imbalance between the water absorbed by the root system and that transpired by the leaves through the day, regardless of the condition of the water supply, due to the oscillation of the evaporative demand of the atmosphere along the day. Even considering the limitation of the instantaneous photosynthetic measurements, it is important to highlight that among the five most productive cultivars in the present study, 'M 734', 'BRS 322', and 'CF 101' displayed the greatest Pn (Table 3). In addition, the highest Pn were supported by high gs and, consequently, a great water loss by transpiration and low Pn/gs. In addition, 'Aguara 4', achieved a high achene and oil yields, despite its great water loss through stomata by transpiration and, consequently, its lower Pn. Therefore, we suppose that if 'Aguara 4' was grown under more severe water stress, this cultivar would provide fewer grains than the cultivars with a greater stomatal closure.

\section{Conclusions}

1. The sunflower (Helianthus annuus) cultivars providing the highest yield in the Brazilian Northeast semiarid region, with supplementary irrigation, are 'Aguara 4', 'CF 101', 'BRS 322' with a high achene and oil yields, and 'M 734' with a high achene yield; and the less susceptible cultivars to severe water deficit are 'Helio 251' and 'BRS 387' with a high-intrinsic photosynthetic efficiency.

2 . There is a narrow variation among the sunflower cultivars for the net photosynthetic rate in the semiarid conditions under supplementary irrigation.

\section{Acknowledgments}

To Empresa Brasileira de Pesquisa Agropecuária (Embrapa), for financial support (SEG: 02.12.12.006.00.00).

\section{References}

ABOUDRARE, A.; DEBAEKE, P.; BOUAZIZ, A.; CHEKLI, H. Effects of soil tillage and fallow management on soil water storage and sunflower production in a semi-arid Mediterranean climate. Agricultural Water Management, v.83, p.183-196, 2006. DOI: https://doi.org/10.1016/j.agwat.2005.12.001.

AGRITEMPO: sistema de monitoramento agrometeorológico. Available at: <http://www.agritempo.gov.br>. Accessed on: May 152017.

ANASTASI, U.; SANTONOCETO, C.; GIUFFRÈ, A.M.; SORTINO, O.; GRESTA, F.; ABBATE, V. Yield performance and grain lipid composition of standard and oleic sunflower as affected by water supply. Field Crops Research, v.119, p.145-153, 2010. DOI: https://doi.org/10.1016/j.fcr.2010.07.001.

BIRCK, M.; DALCHIAVON, F.C.; STASIAK, D.; IOCCA, A.F.S.; HIOLANDA, R.; CARVALHO, C.G.P. Performance of sunflower cultivars at different seeding periods in central Brazil. Ciência e Agrotecnologia, v.41, p.42-51, 2017. DOI: https://doi.org/10.1590/1413-70542017411021216.

BRASIL. Ministério da Indústria, Comércio Exterior e Serviços. Comex Vis: principais produtos importados. 2018. Available at: $\quad<$ http://www.mdic.gov.br/comercio-exterior/estatisticas-decomercio-exterior/comex-vis/frame-ppi?ppi=2171>. Accessed on: July 122018.

CARVALHO, C.G.P. de; CALDEIRA, A.; CARVALHO, L.M. de; CARVALHO, H.W.L. de; RIBEIRO, J.L.; MANDARINO, J.M.G.; RESENDE, J.C.F. de; SANTOS, A.R. dos; SILVA, N.R. da; ARRIEL, N.H.C. Fatty acid profile of sunflower achene oil from the brazilian Semi-arid region. Journal of Agricultural Science, v.10, p.144-150, 2018.

CASADEBAIG, P.; GUILIONI, L.; LECOEUR, J.; CHRISTOPHE, A.; CHAMPOLIVIER, L.; DEBAEKE, P. SUNFLO, a model to simulate genotype-specific performance of the sunflower crop in contrasting environments. Agricultural and Forest Meteorology, v.51, p.163-178, 2011. DOI: https://doi.org/10.1016/j. agrformet.2010.09.012.

CECHIN, I.; CORNIANI, N.; FUMIS, T. de D.; CATANEO, A.C. Differential responses between mature and young leaves of sunflower plants to oxidative stress caused by water deficit. Revista Ciência Rural, v.40, p.1290-1294, 2010. DOI: https://doi.org/10.1590/S0103-84782010000600008.

CHIMENTI, C.A.; HALL, A.J. Grain number responses to temperature during floret differentiation in sunflower. Field Crops Research, v.72, p.177-184, 2001. DOI: https://doi.org/10.1016/S0378-4290(01)00175-7.

DALCHIAVON, F.C.; CARVALHO, C.G.P. de; AMABILE, R.F.; GODINHO, V. de P.C.; RAMOS, N.P.; ANSELMO, J.L. 
Características agronômicas e suas correlações em híbridos de girassol adaptados à segunda safra. Pesquisa Agropecuária Brasileira, v.51, p.1806-1812, 2016. DOI: https://doi.org/10.1590/ S0100-204X2016001100002.

GAROFALO, P.; RINALDI, M. Leaf gas exchange and radiation use efficiency of sunflower (Helianthus annuus L.) in response to different deficit irrigation strategies: from solar radiation to plant growth analysis. European Journal of Agronomy, v.64, p.88-97, 2015. DOI: https://doi.org/10.1016/j.eja.2014.12.010.

GHAFFARI, M.; TOORCHI, M.; VALIZADEH, M.; SHAKIBA, M.R. Morpho-physiological screening of sunflower inbred lines under drought stress condition. Turkish Journal of Field Crops, v.17, p.185-190, 2012.

GRUNVALD, A.K.; CARVALHO, C.G.P. de; LEITE, R.S.; MANDARINO, J.M.G.; ANDRADE, C.A. de B.; SCAPIM, C.A. Predicting the oil contents in sunflower genotype seeds using near-infrared reflectance (NIR) spectroscopy. Acta Scientiarum. Agronomy, v.36, p.233-237, 2014. DOI: https://doi.org/10.4025/ actasciagron.v36i2.17677.

HUSSAIN, M.; FAROOQ, S.; HASAN, W.; UL-ALLAH, S.; TANVEER, M.; FAROOQ, M.; NAWAZ, A. Drought stress in sunflower: Physiological effects and its management through breeding and agronomic alternatives. Agricultural Water Management, v.201, p.152-166, 2018. DOI: https://doi.org/10.1016/j.agwat.2018.01.028.

IBGE. Instituto Brasileiro de Geografia e Estatística. Projeto levantamento e classificação do uso da terra: uso da terra no estado de Sergipe. Relatório técnico. Rio de Janeiro, 2011. 195p. Available at: <https://biblioteca.ibge.gov.br/visualizacao/livros/ liv95889.pdf $>$. Accessed on: Apr. 62020.

KAYA, M.D.; BAYRAMIN, S.; KAYA, G. The effect of planting geometry and seed priming on sunflower yield under rain-fed conditions. Fresenius Environmental Bulletin, v.24, p.4095-4101, 2015. Available at: <https://www.researchgate.net/ publication/292476087>. Accessed on: May 102018.

KROL, M.S.; BRONSTERT, A. Regional integrated modelling of climate change impacts on natural resources and resource usage in semi-arid Northeast Brazil. Environmental Modelling \& Software, v.22, p.259-268, 2007. DOI: https://doi.org/10.1016/j. envsoft.2005.07.022.

LAMAOUI, M.; JEMO, M.; DATLA, R.; BEKKAOUI, F. Heat and drought stresses in crops and approaches for their mitigation. Frontiers in Chemistry, v.6, art.26, 2018. DOI: https://doi.org/10.3389/fchem.2018.00026.

LIU, J.; SHI, D.-C. Photosynthesis, chlorophyll fluorescence, inorganic ion and organic acid accumulations of sunflower in responses to salt and salt-alkaline mixed stress. Photosynthetica, v.48, p.127-134, 2010. DOI: https://doi.org/10.1007/s11099-0100017-4.

MARENGO, J.A.; BERNASCONI, M. Regional differences in aridity/drought conditions over Northeast Brazil: present state and future projections. Climatic Change, v.129, p.103-115, 2015. DOI: https://doi.org/10.1007/s10584-014-1310-1.

MARENGO, J.A.; TORRES, R.R.; ALVES, L.M. Drought in Northeast Brazil - past, present, and future. Theoretical and Applied Climatology, v.129, p.1189-1200, 2017. DOI: https://doi.org/10.1007/s00704-016-1840-8.

MOURA, M.M.; FONTES, C. dos S.; SANTOS, M.H. dos; ARAUJO FILHO, R.N. de; HOLANDA, F.S.H. Estimativa de perda de solo no Baixo São Francisco sergipano. Scientia Agraria, v.18, p.126-135, 2017. DOI: https://doi.org/10.5380/rsa. v18i2.50143.

OLIVEIRA, A.C.B. de; ROSA, A.P.S.A. da. (Ed.). Guia prático do cultivo do girassol. Brasília: Embrapa, 2013. 53p.

ONEMLI, F.; GUCER T. Response to drought of some wild species of Helianthus at seedling growth stage. Helia, v.33, p.4554, 2010. DOI: https://doi.org/10.2298/HEL1053045O.

PEKCAN, V.; EVCI, G.; YILMAZ, M.I.; BALKAN NALCAIYI, A.S.; ÇULHAE RDAL, S.; CICEK, N.; EKMEKCI, Y.; KAYA, Y. Drought effects on yield traits of some sunflower inbred lines. Agriculture and Forestry, v.61, p.101-107, 2015. DOI: https://doi.org/10.17707/AgricultForest.61.4.10.

RAUF, S.; SADAQAT, H.A. Identification of physiological traits and genotypes combined to high achene yield in sunflower (Helianthus annuus L.) under contrasting water regimes. Australian Journal of Crop Science, v.1, p.23-30, 2008.

ROSA, P.M.; ANTONIASSI, R.; FREITAS, S.C.; BIZZO, H.R.; ZANOTTO, D.L.; OLIVEIRA, M.F.; CASTIGLIONI, V.B.R. Chemical composition of Brazilian sunflower varieties. Helia, v.32, p.145-155, 2009. DOI: https://doi.org/10.2298/ HEL0950145R.

SABA, M.; KHAN, F.A.; SADAQAT, H.A.; RANA, L.A. Estimation of diversity and combining abilities in Helianthus annuиs L. under water stress and normal conditions. Genetics and Molecular Research, v.15, gmr15048670, 2016. DOI: https://oi.org/10.4238/gmr15048670.

SANTOS, H.G. dos; JACOMINE, P.K.T.; ANJOS, L.H.C. dos; OLIVEIRA, V.A. de; LUMBRERAS, J.F.; COELHO, M.R.; ALMEIDA, J.A. de; ARAUJO FILHO, J.C. de; OLIVEIRA, J.B. de; CUNHA, T.J.F. Sistema brasileiro de classificação de solos. 5.ed. rev. e ampl. Brasília: Embrapa, 2018. 356p.

SILVA, A.R.A. da; BEZERRA, F.M.L.; LACERDA, C.F. de; PEREIRA FILHO, J.V.; FREITAS, C.A.S. de. Trocas gasosas em plantas de girassol submetidas à deficiência hídrica em diferentes estádios fenológicos. Revista Ciência Agronômica, v.44, p.8693, 2013. DOI: https://doi.org/1590/S1806-66902013000100011.

SOUZA, V.F. de O.; SANTOS, G.L. dos; MAIA, J.M.; MENESES, C.H.S.G.; RODRIGUES, M.H.B.S; DIAS, T.J. Edaphoclimatic conditions of the Brazilian Semi-Arid Region affect the productivity and composition of sunflower oil. Journal of Agricultural Studies, v.7, p.309-322, 2019. DOI: https://doi.org/10.5296/jas.v7i4.15580.

TABATABAEI, S.A.; RAFIEE, V.; SHAKERI, E.; SALMANI, M. Responses of sunflower (Helianthus annuus L.) to deficit irrigation at different growth stages. International Journal of Agriculture: Research and Review, v.2, p.624-629, 2012.

TAIZ, L.; ZEIGER, E. Fisiologia vegetal. 5.ed. Porto Alegre: Artmed, 2012. 
UCAK, A.B. Identification of sunflower (Helianthus annuus L.) genotypes tolerant to water stress. Journal of Agricultural Sciences, v.24, p.312-322, 2018. DOI: https://doi.org/ 10.15832/ ankutbd.456645.
ZLATEV, Z.; LIDON, F.C. An overview on drought induced changes in plant growth, water relations and photosynthesis. Emirates Journal of Food and Agriculture, v.24, p.57-72, 2012. DOI: https://doi.org/10.9755/ejfa.v24i1.10599. 